\title{
Governing-through-Harm and Public Goods Policing
}

Julie Berg and Clifford Shearing

Corresponding Author:

Julie Berg

Scottish Centre for Crime and Justice Research

School of Social and Political Sciences

University of Glasgow

Glasgow G12 8LR

United Kingdom

+44(0)1413301772

Julie.Berg@glasgow.ac.uk

Clifford Shearing

Institute for Safety Governance and Criminology

Department of Public Law

Kramer Law Building

Middle Campus

University of Cape Town

Rondebosch 7700

South Africa

+27(0)216502673

Clifford.Shearing@uct.ac.za 


\section{Bios}

Julie Berg is at the Scottish Centre for Crime and Justice Research at the University of Glasgow. Prior to this, she was an associate professor in the Department of Public Law and the director of the Institute for Safety Governance and Criminology at the University of Cape Town. She was also the interim research chair in security and justice, an award made by the Department of Science and Technology/National Research Foundation, South Africa.

Clifford Shearing holds professorships at the Universities of Cape Town, Griffith, and Montreal and positions at the University of New South Wales and the Durban University of Technology. His recent books include Security in the Anthropocene (with Cameron Harrington, Transcript 2017) and Criminology and the Anthropocene (with Cameron Holley, Routledge 2017).

\section{NOTE}

This work is, in part, based on research supported by the South African National Research Foundation (NRF), grant number 47303. Any opinions, findings, conclusions, or recommendations expressed in this material are those of the authors and the NRF does not accept any liability in this regard.

\footnotetext{
Abstract

Among scholars of law and crime and practitioners of public safety, there is a pervasive view that only the public police can or should protect the public interest. Further, the prevailing perception is that the public police predominantly governs through crime - that is, acts on harms as detrimental to the public good. We argue that governing harm through crime is not always the most effective way of producing public safety and security and that the production
} 
of public safety is not limited to public police forces. An approach of governing-throughharm that uses a variety of noncrime strategies and private security agents as participants in public safety is often more effective - and more legitimate - than the predominant governingthrough-crime approach. We reflect on case studies of noncrime intervention strategies from the Global South to bolster the case for decoupling the link between the public police and public goods. A new theoretical framing needs to be pursued.

Keywords: harm; policing; public good; Global South

There has been a pervasive assumption - among both scholars and practitioners - that only the public police can deliver safety as an inclusive public peace that "promote[s] the objectives and concerns of "society"' (Shearing and Wood 2003a, 205). Evidence for this can be found in the fact that until very recently public inquiries into policing (and there have been many across the Anglosphere) have, focused largely on state police agencies, for instance, the 2015 US President's Task Force report on 21 "Century Policing (President's Task Force on 21st Century Policing 2015). The other side of this framing has been the assumption that private providers of safety, by definition, provide safety services that are exclusive and partisan. Central to this framing has been the idea that public and "private peaces" (Maitland 1885) constitute separate domains that do not overlap — public policing agents support an inclusive public interest while private policing agents support exclusive private interests. This framing, with echoes of Thomas Hobbes (1648/1991) and his "war of all against all" as the outcome of the rampant pursuit of private interests, has a long history that goes back at least to Maitland (1885), who traced a movement through which private peaces were "swallowed up" by a single inclusive public peace. Accordingly, for many, and indeed perhaps most scholars, policy makers and security practitioners, established public policing institutions 
have been viewed as something of an end point in the emergence of a monopoly of policing by public police organizations that has enabled many contemporary societies to realize Maitland's "swallowing up". These developments, it is argued, have, to borrow a term from Loader and Walker (2007), been progressively "civilizing security." Through this process, public policing agencies, by moving ever closer to establishing a monopoly over policing, have been able to successfully bring an end to the inequities associated with partisan policing and the private peaces associated with it, that were such a concern historically.

Within this context, evidence began to appear in the mid-to-late twentieth century, that private forms of policing, and particularly private security employed by and acting on behalf of private authorities, far from being in decline as a state policing monopoly gained ground, were in fact growing rapidly (Cunningham and Taylor 1985; Kakalik and Wildhorn 1972; Spitzer and Scull 1977). Today it is widely agreed that private security in many parts of the globe outnumber public police and draw far greater investments (Abrahamsen and Williams 2009) and engage in most of the functions associated with the public police (Stenning 2000). For instance, in South Africa the private security industry is worth approximately USD4 billion and outnumbers the public police by approximately 3 to 1 in that there are 889 security personnel per 100,000 of the population compared to the public police, which constitutes about 276 personnel per 100,000 of the population of South Africa (Berg and Howell 2017). This has raised concerns, indeed alarm, that policing, instead of successfully realizing inclusive public goods that benefit the many rather than the few (we eschew here economic conceptions of public goods based on notions such as nonexcludable and nonrivalrous) in fact has been quietly sliding back into older forms where exclusive private and club goods (where membership defines one's ability to access goods) are realized at the expense of more inclusive public goods (Crawford 2006; Hope 2000). This, it has been argued, has led to the emergence of increasing inequalities with respect to access to safety (see, for example, Bayley 
and Shearing 1996) - inequalities that the rise of public policing had been intended to eliminate, notwithstanding occasional setbacks that have been responded to by a long history of reform (Sherman 1978) that has continued to the present day (see for example, the Independent Commission into the Future of Policing in Britain; Stevens 2014).

For many scholars and practitioners committed to advancing public policing, these developments signaled a call to arms (Loader and Walker 2007; Reiner 2000), to buttress and extend the gains of public policing and to roll back the worrying prospect of private "auspices" that would bypass public policing by employing private policing "providers" (Bayley and Shearing 2001) for exclusive partisan interests rather than a more inclusive public interest. The linchpin of these arguments has been a deeply entrenched understanding, with long historical roots, that private and public policing goods are distinct and do not overlap; one is either producing private goods or public goods (Shearing and Wood 2003a).

Although these understandings remain central to what might be thought of as the existing common sense about policing, two developments have been steadily eroding these "ways of seeing" (Smith 1987). First, there are conceptual challenges both within policing and other arenas (such as business studies) to the framing that public and private goods constitute nonoverlapping, either/or sets. At the center of these developments have been arguments premised on the idea that public and private goods constitute overlapping sets - an idea for which Porter and Kramer (2011) have used the term shared values (Ayling, Grabosky and Shearing 2009; Shearing and Wood 2003a). Within these conceptual framings, the provision of safety by private auspices and providers often contributes to the provision of safety as a public good—what Shearing and Wood (2003a) term common goods - in the same way as the provision of safety by public providers, operating under the auspices of states, supports both public interests as well as private interests. 
Policing for a public good means providing services that "promote the objectives and concerns of 'society"' (Shearing and Wood 2003a, 205) or in Black's $(2008,141)$ words "conception of 'the good" that should be pursued" as "publically endorsed values" (Shearing and Wood 2003b, 406). What this means is that both public and private providers of policing can, and do simultaneously, serve both public and private interests. This does not mean there are never occasions when public and private interests contest, but this is so for providers of policing services across the public and private policing spectrum.

Both public and private providers only too often act outside of legal provisions intended to protect the public interest as they respond to demands from citizens for policing services. "[S]tate actors are not necessarily or by definition serving some politically neutral notion of the public good, although this is often assumed to be the case" (Caparini 2006, 269). Similarly, private actors are not necessarily serving entirely partisan interests. In short, the boundaries between public goods and private goods are blurred and both can be simultaneously achieved (Shearing and Wood 2003a). This blurring has been further entrenched through the changing nature of space - mass private property, communal space, or privately owned public spaces (Pops)—resulting in the private policing of invisible "bubbles of safety" (Shearing 1999), that are frequented by the public and seem to be in line with the public interest, yet the rules of governance on those spaces may be vested in private interests (Shearing and Stenning 1981; Shenker 2017). For instance, in London the rise of Pops, such as "large squares, parks and thoroughfares" have the appearance of being public spaces, but private landowners own them and the rules by which they are governed may be different to that of public by-laws for instance (Shenker 2017, 7). This means that those who enter these spaces - such as the general public - may often not be aware that a different set of rules govern these spaces and so may be escorted off that space if they unknowingly break the rules. Similarly, the rise of what Morin and Kern $(1999,73)$ call the "polycrisis" is 
characterized by a proliferation of both old and new harms that disregard fixed boundaries temporal, spatial, and conceptual - and where new landscapes of local and global harms or what we have coined harmscapes (for instance, the hypothesized multifarious harms associated with climate change) further challenge our understandings of "safety" and the conventional notions of discrete public and private entities producing public and private goods, respectively.

Yet the "shared value" that so often creates common ground between Maitland's private and public peaces tends to be hidden by the pervasive tendency to conflate harms (a range of events which constitute some form of injury or damage to individuals, groups or the environment, for instance) with crimes (the means by which some harmful actions are defined and governed) (Hillyard and Tombs 2007) — a meaning that constitutes some harms as harms against the state and thus, by definition, as harms against a public interest. This crime-izing (Muncie 1999; Shearing 1989) of some harms as public interest harms has obscured the extensive overlapping of the private and public provision of safety and presented these as two separate categories of goods. Sparrow $(2014,1,20)$ recognizes this overlapping of private and public goods provision when he writes that "[ $\mathrm{t}]$ he boundary between public and private policing is messy and complex" and furthermore, that "private contributions can and should contribute to public purposes."

A significant implication of this crime-izing of some harms has been to define the public police as the provider of safety, as a public good, while at the same time hiding the extent to which other providers of safety have supported public peace, including the wide network of informal providers. By situating states as the dominant auspices of public policing and their police as the providers of public policing, the paradigm of governingthrough-crime has tended to crowd out alternative paradigms of engaging with harms. This is so despite that it is now increasingly recognized (Hillyard and Tombs 2007) that the 
paradigm of governing-through-crime (Simon 2013) is also not always an effective response to harms to the public peace. In other words, the emphasis on governing-through-crime, that characterized so much of the twentieth century and that continues to have a tenacious hold on responses to harms, is not necessarily in line with the public good or the public interest.

The remainder of this article considers what is meant by, and the implications of, a governing-through-crime paradigm for policing. It also considers an alternative governingthrough-harm paradigm and provides examples of this approach from an African location in the Global South. We conclude with thoughts on alternative ways in which public goods policing can be conceptualized. In doing so we accept Sparrow's $(2014,1)$ argument that 'being in some general sense 'for' or 'against' private security is not helpful, as such views are inadequately nuanced or sophisticated given the variety of issues at stake."

\section{Governing-through-Crime}

As mentioned, by favoring the public police as the primary auspice of public goods policing, one simultaneously buys into a governing-through-crime paradigm. This is because the public police are considered the gatekeepers of the criminal justice system through their decision-making powers with respect to arrests as well as their claim to the monopoly on legitimate violence (Bittner 1967). This is not to suggest that the public police exclusively work within a governing-through-crime paradigm, or that the two paradigms (governingthrough-crime and governing-through-harm) are not both performed by the public or private sector, but it is to suggest that it remains difficult to simultaneously buy into both paradigms as they draw on different mentalities: “... the crucial tension in all areas of regulation is between being punishment-orientated and being problem-orientated" (Braithwaite 2002, x). Our argument is that governing-through-crime is the predominant mentality of the public police in their role as gatekeepers to the criminal justice system, acknowledging also the 
blurring of mentalities between the public police and the private sector (Johnston and Shearing 2003).

Simon $(2013,533)$ defines the governing-through-crime paradigm as follows: "We govern through crime to the extent to which crime and punishment become the occasions and the institutional contexts in which we undertake to guide the conduct of others (or even of ourselves)." Acts are constructed as harms in a particular way. The criminalization of certain harms is "one of the many ways to construct social reality" with crime being "not the object but the product of criminal policy" (Hulsman 2013, 313, italics in original).

The criminalization of harms is not particularly problematic in and of itself-we constantly give meaning to acts through constructing them in certain ways. Further, by focusing state policing on governing crime - to "law enforcement"-rather than on governing harms more generally, the paradigm limits police attention to harms that have been defined, by law, as harming a public good. In doing so, whatever else it may or may not do, a governing-through-crime paradigm works to keep the police, albeit not always successfully, on the "straight and narrow" so to speak, by limiting their ability to use their considerable powers to govern more partisan harms-Maitland's "private peaces." Law, and the crime it enables, is a tool used to understand harmful events and to govern them in ways intended to restrict police attention to policing in support of public goods. Labeling a harm as a crime enables the harm to be governed through the mobilization of state resources, and in particular, its criminal justice assemblage, including police.

For harms that have been criminalized, the criminal justice assemblage operates as a governing pathway that can be mobilized by victims seeking assistance in responding to harms they have suffered, provided these harms are crimes. Encouraging citizens to "call the cops" avoids the dangers of responses by citizens to "take the law into their own hands" and in doing so undermining societal interests. The lynch mob constitutes an emblematic 
example that harks back to Hobbes's "war of all against all." The idea that states should monopolize responses to crime-ized harms constitutes a pathway intended to ensure that a public peace "swallows up" private peaces. The success of police as an institution, has, at least in democratic contexts, become an emblematic symbol of the provision of the public good and hence of good policing.

This success, of course, has its down sides; the most notable being the expense of this pathway and the cementing of the use of punishment/pain as an instrument of governance (Clear 2007). An important feature of this pathway is its postharm orientation, intended to protect the liberties of the innocent (von Hirsch 1993), along with the offender-victim dyad that is central to the assignment of blame and punishment as "just deserts" (von Hirsch 1993). It is both a backward-looking and forward-looking system, focused on proving that a harm was done and allocating a just punishment but also aimed at deterring future harms (Hawkins and Thomas 1984, 14). Criticisms of the effectiveness of these punishment-focused arrangements for governing security, which Braithwaite $(2008,155)$ has termed a "ritual of comfort," are legion across a variety of arenas (see, example, Hillyard and Tombs [2007, 14] who argue that punishment may generate "wider social harms" such as job losses and "ostracism by society" and furthermore end up disproportionately affecting the most vulnerable). Central to the lock-in of this pain-focused paradigm has been, as we have just suggested, the concern that a move away from this state-focused way of responding to harms would open the flood gates of partisan responses to disorder (Johnston and Shearing 2003). As a consequence, notwithstanding the plethora of criticism heaped on this paradigm (De Haan 2013; Clear 2007; Hillyard and Tombs 2007; Hulsman 2013), it has remained a very robust feature of the pathways available for governing security. This is in large part because of the deeply embedded Hobbesian assumption that states, by definition, are the only possible guardians of the public interest. As a consequence, the institutions of criminal justice, and 
the governing-through-crime paradigm that they have long embraced, have tended to crowd out alternative ways of thinking about security governance (Muncie 2000).

Notwithstanding these deeply embedded and entrenched ways of thinking, the empirical reality of security governance, epitomized by the growth of the private security industry globally (Abrahamsen and Williams 2009), has shifted enormously. These shifts have been associated with new ways of thinking about security and its governance, albeit often implicit rather than explicit. This shifting reality has led some policing scholars to suggest that it might well be time to accept both that state arrangements for governing security no longer are as dominant, or as self-evident, as they once were, and look anew at the possibilities that more polycentric forms of security governance present for realizing public goods that promote public interests (Sparrow 2014). The latter is a line of reasoning that the political economists, Elinor and Vincent Ostrom, have long advanced with respect to governance processes more generally (see for example Ostrom, Tiebout, and Warren 1961). It is to these possibilities that we now turn.

\section{Governing-through-Harm}

In seeking an alternative approach to security governance than that of the state-centered, punishment-focused approach, some scholars have argued for adopting an approach focused on harm reduction. One of the arenas where this approach has gained traction is drug-related harms, in particular illicit drugs (see for example, O'Malley $[2009,16]$ where he outlines the need to approach illicit drug use from a utilitarian stance, recognizing that "demonizing" illicit drug use through blaming and punishment may end up increasing the risks to society by preventing users from seeking help and perpetuating "risky practices"). A similar approach has been adopted by corporations in response to property, where reducing losses- 
particularly financial loss (that is, loss of profits, assets, or valuable employees) — has often taken center stage (Shearing and Stenning 1982).

A challenge in shifting paradigms has been the ease-Braithwaite's "ritual[s] of comfort" - of governing-through-crime, given the ready availability of the institutions of criminal justice. Scholars advocating a governing-through-harm approach have confronted issues such as how harms should be conceived (Hillyard and Tombs 2007). An early scholarly attempt to take on this issue was Von Hirsch and Jareborg's (1991) initiative to develop a ratable scale of harms in relation to quality of life, an idea that has recently been revisited by Greenfield and Paoli (2013). Similarly, the Cambridge Crime Harm Index, among others, has sought to provide a means by which the harms of crime can be measured (Sherman, Neyroud, and Neyroud 2016). In a parallel initiative Hillyard and Tombs (2007, 17) have categorized harms into physical harms, financial/economic harms, emotional/psychological harm and cultural harms (see also Muncie 2000 and Pemberton 2007). Many of these initiatives have run into conceptual difficulties as they have sought to find a balance between standardization and relativism - if harms are over-standardized there is a risk of glossing over individual experiences and perceptions. On the other hand, understandings of harms can be so relativized to specific contexts that the task of developing concepts that can be used across contexts is compromised (Hillyard and Tombs 2007; Muncie 2000).

How then might a governing-through-harm approach be developed and why is this worthwhile? A governing-through-harm approach, in contrast to a governing-through-crime approach, does not establish a solution prior to the issue being canvased and understood (Freilich and Newman 2016; Hillyard et al. 2005). A harm-focused approach, it is argued, "starts from a different place," by focusing on the social causes of harms or the "big problem" rather than only on individual agency or "the smaller problem" of finding who 
committed the crime and assigning blame accordingly (Freilich and Newman 2016, 216; Hillyard et al. 2005, 61). For instance, consider the challenge of violent communities - a harm-focused approach may view violence and its causes as a developmental or public health problem requiring interventions in the community to 'treat' or develop the social contexts in which violence occurs, rather than only aimed at arresting perpetrators on an individual and case-by-case basis. Thus, the challenge in developing a governing-through-harm approach has been finding ways of moving beyond the rituals of comfort of a governing-through-crime approach, and finding a starting point that does not assume a solution but searches for one. When the public police are the default responders to a harm - which they invariably are within Global North contexts-criminalization is the default option. As a consequence, in Ratcliffe's terms $(2015,2)$ “on the front line of policing, notions of harm and harm reduction are poorly defined."

To develop this analysis further we reflect on two examples from the Global South to illustrate governing-through-harm approaches in instances where the public police are not the first responders.

\section{Governing-through-Harm: Examples from the Global South}

Our first example focuses on governing-through-harm within a context where resources are relatively abundant and where acts identified as harms are mitigated and prevented through altering the environment in which they take place or opting for "soft" forms of policing rather than always and necessarily resorting to criminalization of the issue. Our second example focuses on governing-through-harm within a context where resources are scarcer. Our two examples are both instances of the provision of security for a "club" good (see below). However, in the first example, we show how private interests, through adopting governingthrough-harm approaches, align to the public interest through the production of positive 
externalities (for instance, a "softer" approach to governing a space, such as beautification practices, for instance, may mean that those who do not contribute to the costs of governing that space, nevertheless benefit from it). The second example is an experiment in an impoverished community aimed at addressing the inequalities in access to policing through the provision of donor funding (or a form of block grant) to enable poor communities to "participate in markets for security" (Bayley and Shearing 1996, 603).

We have opted for examples from the Global South because, as mentioned, the public police are not the first responders (for a variety of reasons, such as lack of capacity, lack of legitimacy, or for strategic and operational reasons they choose not to and allow others to do so). Interestingly in many contexts they are also not expected to be the first responders; in other words, the normative expectation that the public police provide public goods policing is not entrenched, meaning that other forms of nonstate policing continue to flourish. The Global South—Africa, in particular, given its long history of nonstate forms of security-is therefore a useful empirical site to explore nonstate, governing-through-harm practices.

Furthermore, to make our point, the two examples reflect instances of relatively minor harms and the ways in which these harms are mitigated through a harms paradigm. This is not to deny the nature and extent of emerging forms of global harmscapes.

\section{Governing-through-harm as "soft" policing}

Our example of governing-through-harm in a relatively resource rich context is the policing that takes place within City Improvement Districts in Cape Town; internationally similar initiatives go by a variety of names, such as Community, Special, Public, Downtown or Neighbourhood Improvement Districts, to reference but a few signifiers. There are many definitions of Improvement Districts, but generally they are defined as “... publicly sanctioned, yet privately directed organization[s] that [supplement] public services to 
improve shared, geographically defined, outdoor public spaces. ... [they] subscribe to a selfhelp doctrine, whereby a compulsory self-taxing mechanism generates multi-year revenue" (Hoyt 2003, 4-5). Improvement Districts constitute a way of generating a limited tax system to supplement public services within a demarcated, and typically contained, urban space. A significant, and sometimes controversial, feature of Improvement Districts is that they produce "club" (Crawford 2006; Hope 2000) rather than more general public goods, something that is epitomized by the fact that the governing bodies, who are responsible to people within these districts, manage their "taxes" for the benefit of the Improvement District. Within a Global South context, the bulk of these monies are spent on governing security, more often than not through the employment of private security companies.

Improvement Districts are known for their use of preventive strategies, rather than after-the-fact strategies, and for their use of situation prevention tactics, such as shaping or designing physical space to impede unwanted activities, such as sleeping on park benches and aggressive panhandling. Improvement Districts have developed three principal ways of dealing with undesirable people or groups of people. First, they may extract the offending party/ies by removing them from the Improvement District - this is predominantly done through making an arrest with the assistance of the public police, a governing-through-crime response. Second, Improvement Districts may exclude people from the district, a key strategy used by property owners to issue a banning order. Third, Improvement Districts may manage undesirable people or populations through practices that are preventive, proactive, and harmoriented (Button 2004). This makes use of incentives rather than force, for example, by assisting vagrancy and homeless persons (both adults and children) to leave an area so that they can get a meal at a soup kitchen or to find accommodation for the night.

This has little to do with the private security per se-we know private security often adopts a very different and much harder approach to policing (Berg 2010; Singh and Kempa 
2007; more generally, see Rigakos 2002) — and everything to do with the objectives of the residents and businesses who play a significant role in financing these districts. While it is argued that the goods provided are simply "club" rather than public goods, these providers are maintaining safety in public places in much the same way that public police do, and, therefore, these are not simply club goods but public or common goods.

\section{Governing-through-harm through dispute resolution}

Our second example of governing-through-harm is in resource-poor contexts. Here we use the example of Peace Committees. The Peace Committees were created under the auspices of the Community Peace Programme that was founded and directed by one of the authors. The program ran from 1997 to 2009 . Its end was primarily due to internal political dynamics resulting in the South African national government terminating its funding (Froestad and Shearing 2012).

The program's objective was to test the hypothesis that people living in a poor and under-resourced community have the knowledge and the capacity to make a significant contribution to the safety and quality of life of their community without either depending on the police to solve all their problems or resorting to vigilantism and violence to deal with their safety problems themselves - that is they have the capacity to provide public goods while respecting liberties. Peace Committees were piloted in 1998 in an informal settlement called Zwelethemba (hence the Peace Committees are often referred to as the "Zwelethemba Model"). Zwelethemba (meaning place or country of hope) is a neighbourhood with a sizable informal housing sector that is located outside Cape Town (Johnston and Shearing 2003). After much discussion in the community with a project team, headed by one of the authors, it was agreed that a major issue in this particular community was the many relatively small problems in the community, such as unpaid loans and other debts, insults and other forms of 
nuisance, some minor assaults, and so forth. The challenge was that, since many of these issues did not constitute crimes, the police, operating within a governing-through-crime paradigm, were neither willing nor competent to address them. These minor issues, if left unresolved, tended to escalate into more serious issues (serious assault, burnings of dwellings, and so forth). At this stage, the public police (and criminal justice system) often became involved, as these harms could be constructed as crime and could thus be constituted as a public police problem. During many meetings with community members, it became apparent to the project team that there was a desire to develop a harm-reduction initiative that would nip these harms in the bud. Experimentation ensued that led to the development of a scalable mechanism to reduce harm escalation. At the center of this model was the recognition that the instigating harms were often disputes in which victims and offenders oscillated — today's victim was tomorrow's offender and vice versa. For a crime to be constituted, so that a harm could be responded to by the institutions of criminal justice, this fluidity had to be frozen to constitute a victim-offender dyad.

The Zwelethemba Model constituted an arrangement that reflected, and respected, this fluidity, by recognizing harms as disputes that could be responded to before they escalated to a point where they became crimes, and victim and offender roles could be solidified. The model enabled a harm-reduction process in which the aim was not to identify wrongdoers who could be blamed and punished or to deter wrongdoers. Rather the focus was on understanding and resolving disputes to create a "better tomorrow." Instead of assigning blame, the processes drew on the wisdom of community members to identify and resolve the sources of disputes. In short, the aim was not to assign blame but to resolve the underlying problem in ways that restored peace and order, which the disputes had violated. 
It is important to follow the steps. It can be very dangerous to go too quickly for a solution.

You must first see what the cause is. For instance, if one of the disputants cries, show regret, that is not enough, you must ask and tell, try to locate the cause. If not, people will do it again. Before the solution, you must find the underlying cause. You must not jump at a solution. That can be very dangerous. (Peace Committee member cited in Wood, Shearing, and Froestad 2011, 5)

One of the main strengths of the Peace Committees was that it allowed for alternative paradigms for the resolution of harms by exploring and resolving conflicts that produced harms. By avoiding escalation, the dispute resolution processes not only avoided the costs to communities of having minor harms escalate into major ones, it also avoided the huge costs to tax payers associated with criminalizing harms.

The model's restorative processes were both inexpensive and effective in producing "socially inclusive solutions," "oriented toward the future" in a very different way than the punishment paradigm (O’Malley 2009, 17). This was accomplished by situating harms within the context of the community as a whole (Hillyard and Tombs 2007). Community members thought to have the knowledge and capacity to craft a better tomorrow were invited to gatherings where plans of action to create a better tomorrow were formulated and agreed to. The model constituted a mechanism that provided for the public good of safety.

\section{Conclusion}

Our cases have shown how a shift in paradigm and mentality can lead to a process of safety governance that enables private auspices and providers to participate in delivering public goods in ways that complement the provision of public goods by the state. What is clear is that both governing-through-crime and governing-through-harm have a role to play in the provision of public goods and that both public and private auspices and providers can play a 
role in the delivery of public goods. However, if we allow only one paradigm to dominate, we risk undermining the capacity of both public and private actors to play a role in the provision of public goods - public goods meaning that which draws upon the "concerns of 'society"' (Shearing and Wood 2003a, 205) as well as the shared "conceptions of 'the good' that should be pursued" within society (Black 2008, 141). As long as we equate public good provision with the state alone or assume that private governance is diametrically opposite to public good provision, we run the risk of excluding alternative paradigms and institutions from the provision of public safety. Public goods provision need not be restricted to the activities of any single node or institution. Under the appropriate conditions many nodes can provide policing for the public good. The question scholars should be asking is whether a form of security governance is providing a public good, not whether particular institutions (that is, public institutions) fulfil the standards for public goods provision. State and nonstate nodes can, and often do, coproduce public goods in the same way that they can, and often do, undermine the provision of these public goods. Whether a public or a private good, or some combination, is provided is not determined by which node is providing the goods but by the processes involved. Consequently, in studying the nature of goods provision within policing, rather than focusing on who is or is not providing policing, the questions should be how are these goods provided and whether these goods contribute to inclusive and/or exclusive objectives. Identifying the conditions for public goods policing is the start of a process to develop the analytical and theoretical tools needed to decouple public goods from the public sector. 


\section{References}

Abrahamsen, Rita, and Michael C. Williams. 2009. Security beyond the state: Global security assemblages in international politics. International Political Sociology 3:1-17.

Ayling, Julie, Peter Grabosky, and Clifford Shearing. 2009. Lengthening the arm of the law:

Enhancing police resources in the twenty-first century. Cambridge: Cambridge University Press.

Bayley, David, and Clifford Shearing. 1996. The future of policing. Law and Society Review 30 (3): 585-606.

Bayley, David, and Clifford Shearing. 2001. The new structure of policing: Description, conceptualization, and research agenda. Washington, DC: U.S. Department of Justice.

Berg, Julie. 2010. Seeing like private security: Evolving mentalities of public space protection in South Africa. Criminology and Criminal Justice 10 (3): 287-301.

Berg, Julie, and Simon Howell. 2017. The private security complex and its regulation in Africa: Select examples from the continent. International Journal of Comparative and Applied Criminal Justice 41 (4): 273-286.

Bittner, Egon. 1967. The police on skid-row: A study of peace keeping. American Journal of Sociology 32:699-715.

Black, Julia. 2008. Constructing and contesting legitimacy and accountability in polycentric regulatory regimes. Regulation \& Governance 2:137-64.

Braithwaite, John. 2002. Restorative justice and responsive regulation. New York, NY: Oxford University Press.

Braithwaite, John. 2008. Regulatory capitalism: how it works, ideas for making it work better. Cheltenham: Edgar Elgar. 
Button, Mark. 2004. "Softly, softly", private security and the policing of corporate space. In Hard cop, soft cop: dilemmas and debates in contemporary policing, ed. R. Hopkins Burke, 101-13. Cullompton: Willan.

Caparini, Marina. 2006. Applying a security governance perspective to the privatisation of security. In Private actors and security governance, eds. Alan Bryden and Marina Caparini, 263-82. Geneva: LIT / DCAF.

Clear, Todd. 2007. Imprisoning communities: How mass incarceration makes disadvantaged neighborhoods worse. New York, NY: Oxford University Press.

Crawford, Adam. 2006. Policing and security as "club goods": The new enclosures? In Democracy and society and the governance of security, eds. Jennifer Wood and Benoit Dupont, 111-38. Cambridge: Cambridge University Press.

Cunningham, William, and Todd Taylor. 1985. The Hallcrest Report: Private security and police in America. Portland, OR: Chancellor Press.

De Haan, Willem. 2013. Abolitionism and crime control. In Criminological perspectives: essential readings. 3rd ed, eds. Eugene McLaughlin and John Muncie, 422-34. London: Sage.

Freilich, Joshua D., and Graeme R. Newman. 2016. Transforming piecemeal social engineering into "grand" crime prevention policy: Toward a new criminology of social control. Journal of Criminal Law and Criminology 105 (1): 203-32.

Froestad, Jan, with Clifford Shearing. 2012. Security governance, policing, and local capacity. Boca Raton: CRC press.

Greenfield, Victoria A., and Letizia Paoli. 2013. A framework to assess the harms of crimes. British Journal of Criminology 53:864-85. 
Hawkins, Keith, and John M. Thomas. 1984. The enforcement process in regulatory bureaucracies. In Enforcing regulation, eds. Keith Hawkins and John M. Thomas, 322. Boston, MA: Kluwer-Nijhoff.

Hillyard, Paddy, and Steve Tombs. 2007. From "crime" to social harm? Crime Law and Social Change 48:9-25.

Hillyard, Paddy, Christina Pantazis, Steve Tombs, and Dave Gordon. 2005. "Social harm" and its limits? In Criminal obsessions: why harm matters more than crime, eds. Paddy Hillyard, Christina Pantazis, Steve Tombs, Dave Gordon and Danny Dorling, 59-73. London: Crime and Society Foundation.

Hobbes, Thomas. 1648/1991. Leviathan. Edited by C. B. Macpherson. London: Cambridge University Press.

Hope, Tim. 2000. Inequality and the clubbing of private security. In Crime, risk and insecurity, eds. Tim Hope and Richard Sparks, 83-106. London: Routledge.

Hoyt, Lorlene M. 2003. The business improvement district: an internationally diffused approach to revitalization. Cambridge, MA: Department of Urban Studies and Planning, Massachusetts Institute of Technology. Available from www.lorlenehoyt.com/yahoo_site_admin/assets/docs/Hoyt_IDA.325174429.pdf.

Hulsman, Louk H. C. 2013. Critical criminology and the concept of crime. In Criminological perspectives: essential readings, 3rd ed., eds. Eugene McLaughlin and John Muncie, 311-16. London: Sage.

Johnston, Les, and Clifford Shearing. 2003. Governing security: explorations in policing and justice. New York, NY: Routledge.

Kakalik, James, and Sorrel Wildhorn. 1972. Private police in the United States [the Rand Report]. Washington, DC: U.S. Department of Justice, National Institute of Law Enforcement and Criminal Justice. 
Loader, Ian, and Neil Walker. 2007. Civilizing security. Cambridge: Cambridge University Press.

Maitland, Frederic. 1885. Justice and police. London: Macmillan \& Co.

Morin, Edgar, and Anne Brigitte Kern. 1999. Homeland Earth: A manifesto for the new millennium. New York, NY: Hampton Press.

Muncie, John. 1999. The British Criminology Conference: Liverpool, July 1999. Liverpool: British Society of Criminology.

Muncie, John. 2000. Decriminalising criminology. Paper presented at the British Society of Criminology Conference, July 1999. Liverpool, UK.

O’Malley, Pat. 2009. Risk and restorative justice: governing through the democratic minimisation of harms. Legal Studies Research Paper No. 09/88, Sydney Law School, University of Sydney, Australia.

Ostrom, Vincent, Charles M. Tiebout, and Robert Warren. 1961. The organization of government in metropolitan areas: A theoretical inquiry. American Political Science Review 55 (4): 831-42.

Pemberton, Simon. 2007. Social harm future(s): Exploring the potential of the social harm approach. Crime Law and Social Change 48:27-41.

Porter, Michael, and Mark Kramer. 2011. The big idea: Creating shared value: How to reinvent capitalism - and unleash a wave of innovation and growth. Harvard Business Review January-February:1-17.

President's Task Force on 21st Century Policing. 2015. Final report of the President's Task Force on 21st century policing. Washington, DC: Office of Community Oriented Policing Services.

Ratcliffe, Jerry H. 2015. Towards an index for harm-focused policing. Policing 9 (2): $164-$ 82. 
Reiner, Robert. 2000. The politics of the police. Oxford: Oxford University Press.

Rigakos, George. 2002. The new parapolice: Risk markets and commodified social control. Toronto: University of Toronto Press.

Shearing, Clifford. 1989. Decriminalizing criminology: Reflections on the literal and topological meaning of the term. Canadian Journal of Criminology 31 (2): 169-78.

Shearing, Clifford. 1999. Remarks of Professor Clifford Shearing [on zero tolerance policing]. Criminal Law Bulletin 35 (4): 378-83.

Shearing, Clifford, and Philip Stenning. 1981. Modern private security: Its growth and implications. Crime and Justice 3:193-245.

Shearing, Clifford, and Philip Stenning. 1982. Snowflakes or good pinches? Private security's contribution to modern policing. In The maintenance of order in society, ed. Rita Donelan, 96-105. Ottawa: Canadian Police College.

Shearing, Clifford, and Jennifer Wood. 2003a. Governing security for common goods. International Journal of the Sociology of Law 31:205-25.

Shearing, Clifford, and Jennifer Wood. 2003b. Nodal governance, democracy, and the new “denizens." Journal of Law and Society 30 (3): 400-19.

Shenker, Jack. 24 July 2017. The insidious creep of London's pseudo-public land. The Guardian.

Sherman, Lawrence. 1978. Scandal and reform: Controlling police corruption. Berkeley, CA: University of California Press.

Sherman, Lawrence, Peter Neyroud, and Eleanor Neyroud. 2016. The Cambridge Crime Harm Index: Measuring total harm from crime based on sentencing guidelines. Policing: A Journal of Policy and Practice 10 (3): 171-83. 
Simon, Jonathan. 2013. Governing through crime. In Criminological perspectives: Essential readings, 3rd ed., eds. Eugene McLaughlin and John Muncie, 531-546. London: Sage.

Singh, Anne-Marie, and Michael Kempa. 2007. Reflections on the study of private policing cultures: early leads and key themes. In Police occupational culture: new debates and directions, eds. Megan O’Neill, Monique Marks and Anne-Marie Singh, 297-320. Oxford: Elsevier.

Smith, Dorothy E. 1987. The everyday world as problematic: A feminist sociology. Boston, MA: Northeastern University Press.

Sparrow, Malcolm K. 2014. Managing the boundary between public and private policing. New Perspectives in Policing Bulletin September:1-24.

Spitzer, Steven, and Andrew Scull. 1977. Privatization and capitalist development: The case of the private police. Social Problems 25 (1): 18-29.

Stenning, Philip. 2000. Powers and accountability of private police. European Journal on Criminal Policy and Research 8:325-52.

Stevens, John. 2014. Policing for a better Britain. Independent Commission into the future of policing. Essex: Lord Stevens and the Anton Group.

von Hirsch, Andrew. 1993. Censure and sanctions. Oxford: Oxford University Press.

von Hirsch, Andrew, and Nils Jareborg. 1991. Gauging criminal harm: A living-standard analysis. Oxford Journal of Legal Studies 11 (1): 1-38.

Wood, Jennifer, Clifford Shearing, and Jan Froestad. 2011. Restorative justice and nodal governance. International Journal of Comparative and Applied Criminal Justice $35: 1-18$. 